\title{
An essay on American wannabes and the Norwegian quality debate
}

\author{
Zacharias Andreadakis \\ University of Michigan
}

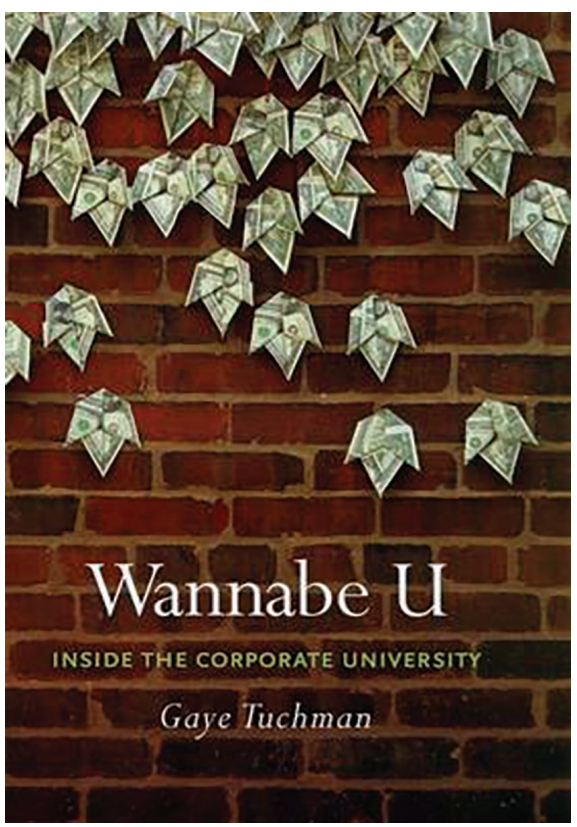

Gaye Tuchman: Wannabe U: Inside the Corporate University, Chicago University Press, 2009, 256 pages.

Norwegian Ministry of Education and Research: Meld. St. 16, 2016-2017 (white paper): Quality Culture in Higher Education, 131 pages.

\section{Foundations of the Wannabe University}

In recent years, the excellent ethnographic study of Wannabe University, the American archetype of the ambitious - but yet not fully established - university, by Gaye Tuchman has already become an instant classic in the study of the sociology of American higher education. However, given its consciously institutional scope, Tuchman's study has, thus far, escaped contrast with sources of broader scope, such as bureaucratic or legislative documents, particularly in the European academic policy context. To remedy this omission, this essay sets out to explore the analytic import of Tuchman's study in interpreting a recent bureaucratic document of the Norwegian

Correspondence: Zacharias Andreadakis, University of Oslo, Department of Education, Faculty of Educational Sciences, Sem Sælands vei 7,0371 Oslo. Email: andreaza@umich.edu (C) 2018 Zacharias Andreadakis. This is an Open Access article distributed under the terms of the Creative Commons Attribution 4.0 International License (https://creativecommons.org/licenses/by-nc/4.0/), allowing third parties to copy and redistribute the material in any medium or format and to remix, transform, and build upon the material for any purpose, even commercially, provided the original work is properly cited and states its license.

Citation: Zacharias Andreadakis. "An essay on american wannabes and the norwegian quality debate» Nordisk tidsskrift for pedagogikk og kritikk,Vol. 4, 2018, pp. 198-205. http://dx.doi.org/10.23865/ntpk.v4.1276 
Ministry of Education and Research (hereafter Meld. St. 16 $1{ }^{1}$ ) and show how the former might inform our understanding of official academic policy discourse in interesting, and perhaps counterintuitive, ways.

Let us start with a bird's eye view on the premises of Tuchman's book. Its overarching argument has a clear priority: to criticize the new economic rationality that has pervaded the university's decision-making, by explaining the effects of "knowledge being now subordinated to the needs of universities for profit and recognition" (p. 11). At the same time, this study sets out to understand this self-imposed auditing culture as nothing more than "a ritual of verification," where honor resides not in traditional core principles but in being number one; or at the very least being in the top twenty-five (p. 12). This association of education with economic prosperity through ranking ambition has produced the discourse of the so-called Wannabe University, a term coined in educational discussions by Michael Arnone (2003: A18). By determining the criteria for the Wannabe University, Tuchman has constructed a useful working hypothesis for understanding the identity of such an aspiring university.

Tuchman's book comprises two conceptual units and ten chapters, both of which pertaining to the issues of competition and commodification of higher education. In the first unit, which concerns the role of marketing and branding, Tuchman sets the scene by briefly outlining the plan of the book, along with an analysis of its ethnographic methodology ("participant observation technique," p. 16), in an effort to capture the specificities and ambiguities of the broader theme of the university's "transformation." Shortly afterwards, the subsequent chapters 2, 3, 4, and 5 situate Wannabe U geographically, historically, and ideologically in the broader landscape of American higher education. The background of the discussion is the pronounced problem of institutional isomorphism, i.e., the search for structural similarity for gaining outside legitimacy, a long-standing, dominant problem in the field of new institutionalism (DiMaggio and Powell, 1983). By branding Wannabe $U$ as a middle-class status conformist university, which sweepingly adopts "best practices" (p. 47), Tuchman explores the de-professionalization that ensues by adopting auditing practices and the emerging issues of mistrust that then burdens the university, pushing it to transition into neo-liberal policies and branding. The analysis scrutinizes the strategies behind the online identity of the university brand, along with the actual advertising of it to the student population, attempting to shed light on the crux of all issues in the modern university, the difficult negotiation between conformity and individuation (p. 49). In the horns of this dilemma, the rest of the unit moves further on the issue of identity politics and transfers us from the general institutional level to the individual.

\footnotetext{
${ }^{1}$ https://www.regjeringen.no/no/dokumenter/meld.-st.-16-20162017/id2536007/https://www.regjeringen.no/contentassets/aee30e4b7d3241d5bd89db69fe38f7ba/en- gb/pdfs/stm201620170016000engpdfs.pdf
} 


\section{Zacharias Andreadakis}

Tuchman proceeds towards analyzing the occupational structure of the newly forged university environments, along with the social-psychological consequences they have for the way the university's agents think about themselves and others. The main line of reasoning is that the university culture seems to be divided in a game of mistrust between two very distinct professional attitudes: the insiders (professors), who see their job as serving the university, and the outsiders (the administrators), who see the university as a career stepping stone. The unit concludes with the investigation of the power play between internal and external forces for the attainment of university resources. In this field, Tuchman offers a critical analysis of the "politics of the present" in the formation of an administrative agenda, which is construed as inherently short-sighted and lacking any philosophy of education in its conception: all the concerns are of an exclusively practical nature, especially with regard to identifying suitable metrics for academic performance. Here, Tuchman shows how Wannabe $U$ tends to follow the mantra of new managerialism on all restructuring decisions towards enhancing competitiveness, however big or trivial: improve organizational rationality to maximize economy, efficiency, and effectiveness (p. 95).

The second conceptual unit turns to a problem germane to the workings of marketing, the tenet of ambition through accountability. In four chapters, Tuchman delves further into Wannabe U's efforts to internalize and tailor itself to the categories of the U.S. News E World Report in order to climb up the rankings ladder. First, it approaches critically the reification of rankings and their logics, by displaying how obsessions with commensuration have changed the form and circulation of information itself, as well as how people attend to it, at the cost of believing in the self-fulfilling prophecy of a success that is far from guaranteed (p. 118). Next, in the magisterial chapter of "Carrots, Sticks, and Accountability," Tuchman moves from the issue of educational commensuration to that of the commodification and consumerism of educational practice - dealing with tertiary education's slow transformation into training. The existential question "what if education is not about informed consumption?" (p. 149), looms large in the exploration of the limits of policy-making imitation among universities. Subsequently, newness in the formation and implementation of lines of action regarding teaching and learning is interpreted as a liability, resulting in both teaching and learning becoming an exercise in appearances. Tuchman follows up with a careful articulation of the problem of continuity in an academic environment, touching upon the quintessential issue of academic freedom and trust between the administration and the professoriate. For her, the corporate culture creates a zero-sum game, with winners and losers in all matters (p. 156). Hence, this entails a cumulative pressure on all parties to perform equally well on all fronts (teaching, research, administration) and, subsequently, unclear priorities, with a prime example being the hiring practices around diversity issues (best and brightest as opposed to first-generation hires). Building upon this premise, Tuchman unravels the circular logic (p. 186) of applications of hyper- instrumental rationality (also known as "McDonaldization" [Ritzer, 1993, 1998, 2000]) in the 
practice of higher education policy. ${ }^{2}$ As a result, Tuchman reveals here the full thrust of her criticism, arguing that the constant preoccupation with efficiency, calculability, predictability, and control leads to conformity and uniformity (p. 188) and that this, in turn, produces "an academic assembly line that militates against intellectual creativity" (p. 188).

Tuchman offers, in the final analysis, a fresh and fine analysis of how the neoliberal change maintains its campus legitimacy and, subsequently, negates potential change by advancing a "business as usual" type of engagement in the slow but real transformation from public to private logics. To her, the university has become irrevocably enmeshed in neo-liberal practices and commensuration logics (i.e., creating a common metric to categorize and make sense of the world). And, unless we unflinchingly resist and confront these neo - liberal logics, the institutional memory of alternative potentials will be eradicated or, to remember Clark citing Machiavelli, temporized until they are believed to be inconsequential (Clark, 1983: 291n8).

\section{The Norwegian Quality in Higher Education Report Meld. St. 16 (2016-2017)}

Contrasting the recent governmental report with Tuchman's contribution seems an unexpected, if fruitful, comparison. Very much unlike the standard Wannabe U logic, the Norwegian Higher Education system, with the exception of very few private institutions, retains a public logic and is committed to the service of the public good. In spite of the fact that Meld. St. 16 is a document of broader scope (macro-political level) than that of a single institution (meso-institutional level), it does employ similar rhetoric and incorporates much of the ongoing debates in Norway qua part of Europe's Bologna agenda. In that sense, the Tuchman's analysis seemed an appropriate foil for the former, since they showcase concurrent logics and examples.

This book-long report addresses several issues of great value for understanding both current Norwegian educational politics in their own right, as well as some longstanding debates on the university's administration. The report, working largely as a facilitator of change between the Ministry and the universities/university colleges, which, nominally at least, retain their role as the principal decision-makers (p. 1), covers a great amount of ground and is divided appropriately into two parts. The first part (pp. 11-26) outlines the theoretical premises of what is understood as quality in higher education and how this quality can be raised (the technical term is kvalitetsløft). The second part, subdivided into six parts, addresses the issues (appearing in order) of the recommended study time and strategies for informed study choice (pp. 29-43), the teaching that produces good learning in conjunction with research (pp. 44-69), the evaluation (and, in essence, the enhanced reception) of the teaching competences of the educational field (pp. 70-79), the role of collegiality and leadership

\footnotetext{
${ }^{2}$ Citing Ritzer 1993, p.186, on "the circle of irrationality of rationality."
} 


\section{Zacharias Andreadakis}

for achieving educational quality (pp. 80- 85), the (national) steering of educational quality (pp. 86-103), and, lastly, the economic and administrative consequences of this process (pp. 104-105). A list of references and four appendices of ministerial documents follow at the end (pp. 106-130).

This report is rich, nuanced, and well-annotated. A thorough analysis of its contents would escape the scope and length of this discussion. Rather, I will address two factors that bear useful similarities to Tuchman's criticisms. First is the outstanding presence of the discourses of ambition and competition in this document. Sometimes, something as simple as a word count may suffice to indicate the spirit of the text. In our case, the word ambition (ambisjon) and its derivatives appear 39 times in all chapters of this document, whereas the word competition (konkurranse) and its derivatives appear 51 times (the document lacks an index, which could have presented an interesting addendum in mapping out the recurrent themes). Perhaps from all the instances of their appearance, however, the following passage in chapter 7 of part 2 is most telling:

Regjeringen har en tydelig ambisjon om at finansieringen av høyere utdanning på sikt i større grad skal baseres på konkurranse. Oppbyggingen av en bred konkurransebasert arena vil skje gradvis. (p. 104)

The government has a clear ambition for the financing of higher education in the long term to be based, to a greater extent, on competition. The construction of a broad competitive arena will occur gradually. (Translation mine)

What I want to draw attention to here even more than the nexus of competition and ambition itself is the term "gradually." Tuchman, on page 202, employs a very telling metaphor: "It's like the proverbial frog in the pot. If you drop the sucker in boiling water, he will jump out; but if you increase the heat slowly enough, he eventually finds himself boiled." Here, a similar picture cannot but be seen: the gradual and long-term character of this process entails a danger of impossibility to identify the change and resist it, if need be.

Next in line is the prerogative for the commodification of education, along with its own linkage with economic growth. The conclusion of the report states this very succinctly: the competence level of the population is a decisive factor for economic growth and productivity, and higher education is an important instrument for Norway to be able to manage the transition from a resource economy to a knowledge economy. ${ }^{3}$ In light of Tuchman's contribution on the marketization of knowledge to its conversion as directly translatable into capital (p. 59, with the very relevant discussion of how the Bay- Dole Act of 1983 has allowed this direct equation between knowledge/

\footnotetext{
${ }^{3}$ Meld. St. 16 (2016-2017), 104: "Befolkningens kompetansenivå er en avgiørende faktor for økonomisk vekst og produktivitet, og høyere utdanning er et viktig virkemiddel for at Norge skal kunne håndtere overgangen fra ressursøkonomi til kunnskapsøkonomi.”
} 
patent inventions and capital), the discussion and language of the report cannot but alert us to its convergence with USA's private goods logic.

Now, I must remark that the similarity between the educational discourses of aspiring or "wannabe" universities in the US and the Norwegian interpretation of competition is striking; the two are arguably "variations of the same theme," as Crina Damşa et al. put it in their report (2015:21). Norway, a country with a traditionally strong state steering (Damşa et al., 2015: 23), seems in the context of this document to be drifting now in a new, different, "wannabe" direction. So far, Norwegian quality policies of higher education of the previous two decades until 2004 have been described as having a "softer, more experimental design, with several objectives linked to policy-learning" (Stensaker, 2004: 14; see also Stensaker, 1997, 1998), where "these policies were based more on pedagogical and communicative measures" (Stensaker, 2004: 14), and with Norway being characterized as a place renowned for being a reluctant and slow reformer of higher education (Maassen 1996: 10; Bleiklie et al. 2000; Bleiklie 2004). Nonetheless, Norway's turn to neo-liberal educational policies and the application of new public management strategies have not been conceived as being as intense as other countries (Bleiklie and Kogan 2007; Damşa et al. 2015: 23).

Of course, in a globalized educational context, there has been a local increase in market rationales and market logics (Maassen et al., 2008, 2011; Damşa et al., 2015: 23). However, this report revisits past rhetoric quite radically, at least in its wording, and definitely shifts it to a more urgently "wannabe" one, where Tuchman's three E's (p. 22) of audit culture dominate in the pursuit of elevated status: economy, efficiency and effectiveness. The actual consequences of such initiatives remain to be seen. However, the "creeping" wave of neo-liberal policies in education that Tuchman's critiques has definitely made its presence felt in Norwegian Higher Education policy discourse and has gained ground in establishing its legitimacy.

\section{Conclusion}

Any study of such scope and ambition as Tuchman's will have blind spots. The strength of this book, namely, the lively familiarization with ongoing tensions in professional academic life is also its weakness. Tuchman does not fully take into account the argumentative merits of the opposing, "auditing culture" side, nor does she anticipate the potential criticism of her argument. This uneven approach leads to a missed opportunity to break open the discussion in the field about salient if unintended elitistic logics in academia (Getman, 1992; DeMillo and Young, 2015). Of course, one should not forget that this book was published in the aftermath of the second largest financial crisis in modern history, where auditing and rating companies have lost much of their credibility and cultural capital. Still, examining the practices of accountability should also perhaps include examining the roots of the problem in some depth, not merely its practical consequences and manifestations. Ultimately, in this way, we could further unveil how and to what extent the current university field is sustainable. 


\section{Zacharias Andreadakis}

It is impossible to capture the intricacy of Tuchman's uncompromising inclusion of the endemic tensions and debates in the operations of higher education in the capitalist economic paradigm. The erudite mastery over the scholarly references and the forcefully simple language will continue to nurture productive discussion in the field of higher education, as well as outside the walls of academia, on both a national and an international level. One need not agree with all her approaches or conclusions to profit from them. Indeed, this study, as it has been previously remarked (Stevens 2010: 1042-1043) does not intend to advance the academic discourse of commodification of higher education per se and makes no pretense to do so. It does, however, critically subsume and condense some of the open academic issues and tensions in the global attempt to climb up the rankings ladder, by providing a clear overview of the stakes of the debate to stakeholders both within and outside the campus. What is more, the writing style of the volume, composed as a novelistic essai with footnotes, is a significant statement in itself: an invitation regarding the appropriate discourse for tackling the difficulties of academic endeavors as more than an esoteric academic issue, but rather as an open, pressing, and public issue. ${ }^{4}$ In that respect, Tuchman's book offers a very rich insight in to the mechanisms and subsisting vocabularies that gave birth to the assumptions and arguments behind Meld. St. 16 and the rhetoric of competitiveness. And it calls for the reader's immediate attention, be that from Norwegian or abroad, to the dangers and logical fallacies behind this pullulating rhetoric.

\section{References}

Arnone, M. (2003). "The Wannabes.” Chronicle of Higher Education 49 (17) (January 3): A18.

Bleiklie, I. (2004). "Norway: Holding Back Competition?" In Controlling Modern Government, C. Hood, O. James, G. Peters, \& C. Scott (Eds.), (pp. 114-118). London: Edward Elgar.

Bleiklie, I., \& Kogan, M. (2007). Organization and Governance of Universities. Higher Educaction Policy 20 (4), 477-493.

Bleiklie, I., Høstaker, R., \& Vabø, A. (2000). Policy and Practice in Higher Education. London: Jessica Kingsley.

Clark, B. R. (1983). The Higher Education System: Academic Organization in Cross-National Perspective. Berkeley: University of California Press.

Damşa, C., de Lange, T., Elken, M, Esterhazy, R., Fosseland, T., Frølich, N., Hovdhaugen, E., Maassen, P., Nerland, M. B., Nordkvelle, Y. T., Stensaker, B., Tømte, C., Vabø, A., Wiers Jenssen, J., \& Aamot, P.O. (2015). Quality in Norwegian Higher Education: A Review of Research on Aspects Affecting Student Learning. Rapport 2015/24. NIFU.

DeMillo, R. A. \& Young, A. (2015). Revolution In Higher Education: How A Small Band of Innovators Will Make College Accessible And Affordable. Cambridge, MA: MIT Press.

DiMaggio, P. J. \& Powell, W. W. (1983). "The Iron Cage Revisited: Institutional Isomorphism and Collective Rationality in Organizational Fields." American Sociological Review 48: 147-160.

Getman, J. G. (1992). In The Company Of Scholars: The Struggle For The Soul of Higher Education. Austin: University of Texas Press.

Maassen, P. A. M. (1996). Governmental Steering and the Academic Culture: The Intangibility of the Human Factor in Dutch and German Universities. Utrecht: De Tijdstroom.

${ }^{4}$ The lasting impact of this open writing style can be also traced in the most recent work of Magolda 2016 , with much overlap in the themes treated and in style of analysis. 


\section{An essay on American wannabes and the Norwegian quality debate}

Maassen, P., Vabø, A. \& Stensaker, B. (2008). "Translation of Globalisation and Regionalisation in Nordic Cooperation in Higher Education.” In Borderless Knowledge, Å. Gornitzka and L. Langfeldt (Eds.), (pp. 125-139). Dordrecht: Springer.

Maassen, P., Moen, E., \& Stensaker, B. (2011). "Reforming Higher Education in the Netherlands and Norway: The Role of the State and National Modes of Governance.” Policy Studies 32(5): 479-495.

Magolda, P. M. (2016). The Lives of Campus Custodians: Insights into Corporatization and Civic Disengagement in the Academy. Sterling, VA: Stylus Publishing.

Meld. St. 16 (2016-2017). Kultur for kvalitet $i$ høyere utdanning. Kunnskapsdepartementet.

Ritzer, G. (1993). The McDonaldization of Society. Thousand Oaks, CA: Pine Forge Press.

Ritzer, G. (1998). The McDonaldization Thesis. Thousand Oaks, CA: Pine Forge Press.

Ritzer, G. (2000). The McDonaldization of Society: New Century Edition. Thousand Oaks, CA: Pine Forge Press.

Stensaker, B. (1997). "From Accountability to Opportunity: The Role of Quality Assessments in Norway." Quality in Higher Education 3 (3): 277-284.

Stensaker, B. (1998). "Culture and Fashion in Reform Implementation: Perceptions and Adaptation of Management Reforms in Higher Education.” fournal of Higher Education Policy and Management 20(2): $129-138$

Stensaker, B. (2004). The Transformation of Organisational Identities: Interpretations of Policies Concerning the Quality of Teaching and Learning in Norwegian Higher Education. Enschede: CHEPS/UT.

Stevens, M. L. (2010). "Review of Wannabe U: Inside the Corporate University. By Gaye Tuchman." American Fournal of Sociology 116(3): 1042-1043.

Svensson, G. (2007). "Legal Requirements for Transparency in Appointments and Promotion in Swedish Higher Education Institutions.” International fournal of Public Sector Management 20(2): 118-133. 
